\title{
PENGARUH BRAINSTORMING DAN KEAHLIAN AUDITOR TERHADAP PENILAIAN RISIKO FRAUD DI PTN
}

\author{
Imam Mulyono ${ }^{1}$ Jaswadi $^{2}$, Siti Amerieska ${ }^{3}$ \\ 1,2,3 Jurusan Akuntansi, Politeknik Negeri Malang \\ ${ }^{1}$ imam.mulyono@polinema.ac.id, ${ }^{2}$ jaswadi@polinema.ac.id, ${ }^{3}$ siti.amerieska@polinema.ac.id
}

(Artikel diterima: November 2019, diterima untuk terbit: Desember 2019)

\begin{abstract}
Abstrak - Tujuan dari penelitian ini, untuk menguji apakah brainstorming dan keahlian auditor berpengaruh terhadap penilaian risiko fraud, dengan brainstorming dan keahlian auditor sebagai variable independen, dan penilaian risiko fraud sebagai variable dependen. Sampel berjumlah 50 kepada Internal Auditor (Perangkat SPI) PTN dari 14 PTN di Jawa Timur, dengan mendistribusikan kuisioner 50 kuisioner dan 46 kuisioner yang direspon oleh responden. Metode analisis data yang digunakan adalah uji kualitas data, uji asumsi klasik, uji hipotesis dengan regresi linier berganda, berdasarkan hasil analisis data yang sudah dilakukan bahwa brainstorming dan keahlian auditor berpengaruh terhadap penilaian risiko fraud. Hasil penelitian menunjukkan bahwa brainstorming berpengaruh terhadap penilaian risiko fraud karena tanpa proses Brainstorming yang tepat, tugas dan kinerja auditor akan terancam, dan auditor mungkin tidak mampu mengidentifikasi risiko fraud selama penilaian risiko fraud serta dengan Brainstorming mendorong auditor untuk mengadakan diskusi dengan anggota tim audit tentang potensi materi salah saji karena fraud. Keahlian auditor berpengaruh terhadap penilaian risiko fraud karena penilaian risiko fraud harus dilakukan oleh Auditor yang memiliki keahlian dan pelatihan yang cukup sebagai Auditor dan bertindak sebagai seorang yang ahli dalam bidang akuntansi dan bidang auditing melalui pendidikan formalnya yang diperluas dengan pengalaman-pengalaman selanjutnya dalam praktik audit.
\end{abstract}

Kata kunci: Brainstorming, Keahlian Auditor, Penilaian Risiko Fraud.

\section{Pendahuluan}

Pada saat ini, di Indonesia terdapat kurang lebih 4.400 perguruan tinggi dengan 7 juta orang mahasiswa dan 250 ribu dosen (Ardika, Sitawati, \& Suciani, 2013). Kemristekdikti mengelola keuangan negara sekitar 41,2 Trilyun dan membawahi ratusan satker dengan berbagai karakteristik organisasinya (paparan Irjen 2018). Meskipun per 2017, Kemristekdikti mendapatkan opini WTP dari BPK, bukan berarti laporan keuangan yang dihasilkan terbebas dari kondisi fraud.

Dalam tahapan perencanaan audit, auditor harus menentukan tipe dan ukuran resiko kecurangan (Kerr, 2013). Selanjutnya, Nurharyanto (2009:19) menjelaskan upaya penciptaan lingkungan pengendalian sehingga pemahaman tentang fraud telah diberi batasan dan definisi yang lebih konkrit, dan memperluas kewenangan dalam tanggung jawab pembuatan kebijakan anti-fraud di level pimpinan institusi, termasuk langkah-langkah pencegahan (prevention) dan pendeteksian (detection) fraud. Pungujian pengendalian intern secara berkala yang dilakukan oleh para pucuk pimpinan instansi, akan menjadi tidak bermakna apabila fraud dalam skala besar terlambat diketahui terjadinya. Pimpinan instansi akan dihadapkan pada potensi kerugian yang besar, baik dari jumlah nilai uang, risiko reputasi, karir, bahkan ancaman hukum yang sangat berat (Bastian, 2003: 48).

fraud adalah tindakan yang disengaja yang dilakukan oleh seseorang atau lebih dalam tim manajemen, pengawas, karyawan, pihak ketiga, dengan cara menipu untuk memperoleh keuntungan tidak halal/melawan hukum (Tuanakota, 2016:194), Audit laporan keuangan bersamaan dengan penilaian risiko fraud dapat mempengaruhi kinerja penilaian risiko fraud (Knapp dan Knapp, 2001). Praktek bersamaan seperti itu dilakukan karena waktu yang terbatas, selain itu, tekanan publik memaksa auditor untuk melakukan penilaian risiko fraud bersamaan dengan pernyataan audit keuangan (Braun, 2000). Karena itu, auditor perlu menilai risiko fraud yang ada dalam suatu organisasi dan pada saat yang sama waktu melakukan audit laporan keuangan.

Brainstorming mengumpulkan sekelompok orang, dengan tujuan menghasilkan pikiran-pikiran yang baru dan segar (Minter \& Michael dalam Priyatno, 2007:57). Dalam penilaian risiko fraud, brainstorming mendorong anggota tim audit untuk berbagi informasi klien, indikator risiko fraud, dan pengalaman fraud, serta untuk alat transfer pengetahuan antara anggota tim identifikasi risiko fraud (Kerr, 2013).

Berdasarkan uraian diatas, rumusan masalah penelitian ini, adalah: (1) Apakah brainstorming dan keahlian auditor berpengaruh pada penilaian risiko fraud? (2) Bagaimana dampak brainstorming dan keahlian auditor terhadap penilaian risiko fraud?. Batasan masalahnya penyebaran kuisioner dan wawancara dengan Tim Satuan Pengawasan Internal selaku Auditor Internal di 14 (lima) Perguruan Tinggi Negeri di Jawa Timur. Tujuannya (1) Apakah brainstorming dan keahlian auditor berpengaruh terhadap penilaian risiko fraud. (2) Bagaimana dampak brainstorming dan keahlian auditor terhadap penilaian risiko fraud. Manfaat Penelitian ini, adalah; (1) Bagi Peneliti, Peningkatan kompetensi untuk memberikan model solusi terhadap penilaian risiko fraud. (2) Bagi Peneliti Lain, Pengembangan faktor-faktor yang mempengaruhi penilaian risiko fraud. (3) Bagi Institusi, Memberikan kontribusi penguatan dan pengayaan referensi dalam bidang audit, utamanya audit sektor publik. 


\section{Tinjauan PUStaka}

\section{A. Fraud}

Menurut Arent, Randal, dan Mark (2008:437) fraud risk assessment merupakan tonggak penting dalam program anti-fraud untuk mengantisipasi (bukan sekedar bereaksi atas) terjadinya fraud dan penyalahgunaan wewenang. Untuk mengukur penilaian risiko kecurangan dapat dilihat dari lima indikator sebagai berikut ini; (1) Komunikasi antara tim audit, (2) Tanya jawab atau wawancara dengan Klien, (3) Faktor-faktor risiko, (4) Prosedur analitis, dan (5) Informasi lainnya.

Nurharyanto (2009) menjelaskan Penilaian risiko fraud yang efektif akan dapat mengidentifikasi risiko-risiko yang tidak terdeteksi dan memperkuat kemampuan organisasi dalam mencegah dan mendeteksi fraud serta penyalahgunaan sebelum menjadi skandal bagi instansi serta dapat mengidentifikasi penghematan biaya yang timbul dibandingkan dengan biaya penilaian secara langsung. Langkah-langkah yang ditempuh dalam penilaian risiko fraud mencakup; (1) Mengorganisasikan penilaian risiko berdasarkan siklus tugas pokok dan fungsi instansi atau siklus kemungkinan terjadinya fraud, (2) Menetapkan unit dan lokasi untuk dinilai, (3) Mengidentifikasi skema dan skenario potensi terjadinya fraud dan penyalahgunaan wewenang, (4) Menilai kemungkinan terjadinya dan tingkat signifikansi risiko.

Penilaian risiko fraud dengan menggunakan uji pengendalian internal dapat meningkatkan kinerja pada penilaian risiko fraud. (Alles dkk., 2008; Duh et al., 2006). Menurut Alles et al (2008) menggunakan audit secara kontinu dalam uji pengendalian internal untuk mengetahui dampak terhadap kinerja penilaian resiko fraud.

\section{B. Brainstorming dalam Penilaian Resiko Fraud}

Sebagian besar penelitian telah sepakat bahwa proses brainstorming mengarah ke kinerja yang lebih baik (Alon dan Dwyer, 2010; Carpenter, 2007, O'Donnell et al., 2000). Standar Internasional tentang Audit (ISA - International Standart on Auditing) 240 dan Standar Internasional Lembaga-Lembaga Audit Tertinggi (International Standards of Supreme Audit Institutions - ISSAI) 1240 yang mendorong auditor untuk mengadakan diskusi dengan anggota tim audit tentang potensi materi salah saji karena fraud. Standar dan panduan juga mendorong penerapan brainstorming selama tugas dalam penilaian resiko fraud. Namun, karena keterbatasan waktu dan sumber daya, terkadang brainstorming tidak dilakukan dengan tepat oleh auditor pemerintah. Tanpa proses brainstorming yang tepat, tugas kinerja mungkin terancam, dan auditor mungkin tidak mampu mengidentifikasi risiko fraud selama penilaian risiko fraud.

Tujuan dari proses brainstorming adalah untuk memastikan anggota tim keterlibatan berbagi informasi, ide, dan pengalaman. Selama proses brainstorming, informasi tentang triangle fraud, tindakan anti-penipuan dan elemen penipuan didiskusikan (Trompeter et al., 2013). Namun, psikologi literatur melaporkan temuan campuran tentang efek brainstorming terhadap kinerja. Hasil penelitian Dennis dan Valacich (1993) menemukan, bahwa brainstorming tidak menghasilkan lebih banyak ide dalam penelitian mereka, auditor tidak berpartisipasi dalam diskusi dalam eksperimen mereka karena beberapa alasan seperti auditor yunior tidak berkontribusi karena auditor senior atau manajer terlibat dalam sesi brainstorming.

Namun, Carpenter (2007) menemukan bahwa kualitas ide meningkat dengan penurunan jumlah ide selama proses brainstorming dan dengan demikian, meningkatkan efisiensi audit. Sebuah brainstorming diperlukan untuk auditor pemerintah untuk berbagi ide-ide berkualitas dan yang paling penting, untuk memungkinkan transfer pengetahuan di antara anggota tim (Kerr, 2013; Kozloski, 2011). Brainstorming mengarahkan auditor pemerintah untuk fokus pada tugas yang diberikan seperti penilaian risiko fraud menggunakan uji pengendalian internal. Auditor dapat memodifikasi prosedur standar sesuai dengan ide-ide dari sesi brainstorming (Hoffman dan Zimbelman, 2009). Penelitian sebelumnya tentang brainstorming yang digunakan dalam penilaian risiko fraud (Alon dan Dwyer, 2010; Carpenter, 2007, Nasir et all, 2016). O'Donnell et al. (2000) menemukan bahwa brainstorming meningkatkan penilaian pengendalian internal untuk sistem informasi. Hasil penelitian Prasetyo (2018) dengan metode eksperimen membuktikan bahwa ternyata baik kelompok brainstorming dan bantuan keputusan tidak berpengaruh signifikan terhadap penilaian risiko kecurangan.

\section{Keahlian Auditor dalam Penilaian Risiko Fraud}

Penekanan pengetahuan tergantung pada latar belakang pendidikan, dan itu menentukan alasan strategis (Tabak dan Barr, 1999). Dalam rangka menjaga kredibilitas, auditor eksternal harus selalu meningkatkan kemampuan dan keahliannya ketika menjalankan tugasnya. Bahkan dalam mendeteksi kecurangan, auditor ekternal tetap harus memiliki keahlian dan menggunakan keahliannya agar pendeteksian kecurangan ini dapat dilakukan dengan baik. Kategori komponen keahlian yang dimiliki auditor diantaranya adalah; (1) Pengetahuan, (2) Kemampuan menyelesaikan masalah, (3) Kemampuan Individu (Interpersonal Skill), (4) Faktor eksternal (Mui,2009). Menurut Bonner \& Lewis (1990) pengetahuan dan kemampuan menyelesaikan masalah merupakan kriteria penting dalam keahlian kinerja auditor. Kedua keahlian ini bisa menjadi kekuatan seorang auditor dalam menyelesaikan masalah kecurangan.

Di organisasi sektor publik, utamanya organisasi pemerintahan, auditor pemerintah memiliki beragam keahlian karena auditor pemerintah tidak hanya mengaudit laporan keuangan. Meskipun beberapa Badan/Lembaga pemerintah sudah menyediakan pelatihan berkaitan dengan audit, pengendalian internal dan penilaian risiko fraud terhadap auditor pemerintah, masih menghasilkan tingkat pengetahuan yang berbeda karena berbeda latar belakang pendidikan. Contohnya seorang auditor dengan suatu latar belakang pendidikan akuntansi dilatih untuk menilai pengendalian internal menggunakan kerangka pengendalian internal dan juga dalam tugas penilaian audit (LaSalle, 2007). Di sisi lain, seorang auditor tanpa latar belakang pendidikan akuntansi tidak menerima pelatihan yang tepat pada kerangka kerja pengendalian internal, dan dalam skenario terburuk, auditor mungkin tidak memiliki pengetahuan yang berhubungan dengan akuntansi. Selanjutnya, seorang auditor dengan latar belakang pendidikan akuntansi sudah terkena prinsip-prinsip konservatif, dan ini membuat skeptisisme profesional jauh lebih baik. Sedangkan penempatan auditor pemerintah tanpa latar belakang pendidikan akuntansi mungkin melakukan 
kurang efektif pada penilaian risiko fraud. Pendapat lainnya tentang penilaian resiko fraud, adalah penilaian resiko fraud yang baik mengisyaratkan adanya input dari berbagai sumber. Input tersebut dikelola sebagai landasan dan petunjuk untuk melakukan penilaian, oleh karena itu organisasi perlu membentuk tim penilai resiko yang terdiri dari individu-individu yang mewakili sebanyak mungkin unit dari organisasi dengan pengetahuan, ketrampilan dan prespektif yang berbeda-beda dan mesti mencakup sumber daya internal dan eksternal (Purba, 2015:72). Analisa dan hasil penelitian sebelumnya, juga didukung oleh hasil penelitian Nasir et. All (2016) bahwa keahlian auditor akan mempengaruhi hasil penilaian resiko audit.

Dalam standar umum SA seksi 210 tentang pelatihan dan keahlian Auditor Independen yang terdiri atas paragraph 03-05, menyebutkan secara jelas tentang keahlian auditor disebutkan dalam paragraf pertama sebagai berikut "Audit harus dilakukan oleh seseorang atau lebih yang memiliki keahlian dan pelatihan yang cukup sebagai auditor" (SPAP, 2001). Standar Umum pertama tersebut menegaskan bahwa syarat yang harus dipenuhi oleh seorang akuntan untuk melaksanakan audit adalah harus memiliki pendidikan dan pelatihan yang memadai dalam bidang auditing. Kemudian pengalaman seorang auditor juga sangat berperan penting dalam meningkatkan keahlian auditor dalam bidang auditing. Sebagaimana yang telah diatur dalam paragraf ketiga SA seksi 210 tentang pelatihan dan keahlian independen disebutkan: "Dalam melaksanakan audit untuk sampai pada suatu pernyataan pendapat, auditor harus senantiasa bertindak sebagai seorang yang ahli dalam bidang akuntansi dan bidang auditing. Pencapaian keahlian tersebut dimulai dengan pendidikan formalnya yang diperluas melalui pengalamanpengalaman selanjutnya dalam praktik audit (SPAP, 2001)."

Berdasarkan analisa teori dan penelitian sebelumnya maka kerangka dalam penelitian ini, sebagai berikut:

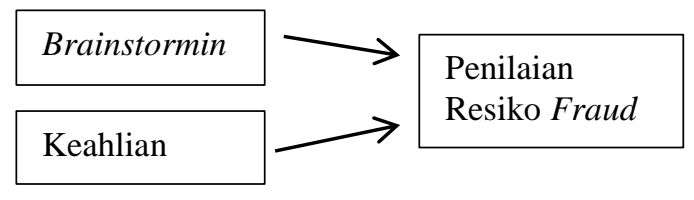

Gambar 2.1. Kerangka penelitian

Mengacu pada rumusan dan tujuan penelitian, maka dibuat hipotesis penelitian sebagai berikut. (1) Hipotesis pertama: Penelitian sebelumnya tentang brainstorming yang digunakan dan mempengaruhi penilaian risiko fraud (Alon dan Dwyer, 2010; Carpenter, 2007; Nasir, 2016) dan Menurut O'Donnell et al. (2000) bahwa brainstorming meningkatkan penilaian pengendalian internal untuk sistem informasi. Oleh karena itu, hipotesis pertama dikembangkan: $\mathrm{H}_{1}$ : Brainstroming berpengaruh terhadap penilaian risiko fraud. (2) Hipotesis kedua: Penelitian sebelumnya bahwa keahlian auditor mempengaruhi penilaian resiko fraud (LaSalle, 2007; Nasir et. All, 2016) serta pendapat Purba (2015:72), dan dalam Mui (2009) serta Bonner \& Lewis (1990) menjelaskan bahwa pengetahuan dan kemampuan menyelesaikan masalah merupakan kriteria penting dalam keahlian kinerja auditor. Kedua keahlian ini bisa menjadi kekuatan seorang auditor dalam menyelesaikan masalah kecurangan. Hasil penelitian di atas sebagai dasar dalam pengembangan hipotesis kedua, yaitu. $\mathrm{H}_{2}$ : Keahlian auditor berpengaruh terhadap penilaian resiko fraud.

\section{Metode Penelitian}

Penelitian ini bertujuan untuk menganalisis pengaruh antara variabel independen yaitu Brainstorming dan Keahlian Auditor serta variabel dependen yaitu Penilaian Resiko Fraud. Variabel dependen yang digunakan dalam penelitian ini adalah Penilaian Resiko Fraud, Pengukuran variabel ini menggunakan skala liker 1 poin sampai 5 poin. Dimana skala 1 (sangat tidak setuju), skala 2 ( tidak setuju), skala 3 (ragu-ragu), skala 4 (setuju), dan skala 5 (sangat setuju). Dimana skala 1 sebagai skala rendah sampai skala 5 sebagai skala tinggi, artinya apabila responden menggunakan skala 1 (rendah) maka tidak berpengaruh signifikan terhadap Penilaian Resiko Fraud dan apabila skala 5 (tinggi) maka berpengaruh signifikan terhadap Penilaian Resiko Fraud. Variabel independen dalam penelitian ini adalah variabel brainstorming dan keahlian auditor. Pengukuran kedua variabel independen ini menggunakan skala liker 1 poin sampai 5 poin. Dimana skala 1 (sangat tidak setuju), skala 2 ( tidak setuju), skala 3 (ragu-ragu), skala 4 (setuju), dan skala 5 (sangat setuju). Dimana skala 1 sebagai skala rendah sampai skala 5 sebagai skala tinggi, artinya apabila responden menggunakan skala 1 (rendah) maka tidak berpengaruh signifikan terhadap brainstorming dan keahlian auditor dan apabila skala 5 (tinggi) maka berpengaruh signifikan terhadap brainstorming dan keahlian auditor.

Populasi dalam penelitian ini adalah seluruh jabatan SPI/Internal Auditor PTN. Teknik pengambilan sampel dilakukan secara purposive sampling dan sampel yang diambil dalam penelitian ini berjumlah 50 (lima puluh) SPI/Internal Auditor PTN. Kuisioner yang disebar sebanyak 50 kuisioner dan peneliti menerima respon kuisioner sebanyak 46 kuisioner. Jenis data yang digunakan dalam penelitian ini adalah data primer, dengan sumber data berasal dari kuisioner yang diisi langsung oleh target responden.

Metode analisis data yang digunakan, antara lain: (1) Uji Kualitas Data yang terdiri dari (a) Uji Validitas, (b) Uji Reliabilitas. (2) Uji Asumsi Klasik, dengan melakukan; (a) Uji normalitas dengan uji statistik nonparametric Kolmogorov-Smirnov (K-S). (b) Uji Multikolonieritas dengan menggunakan Variance Inflation Factor (VIF) dan Tolerance. (c) Uji heteroskedastisitas menggunakan metode Glejser. (2) Uji hipotesis menggunakan Software SPSS Versi 24 untuk memprediksi hubungan antara Penilaian Resiko Fraud (PRF) dan Brainstorming (B) dan Keahlian Auditor (KA). Uji hipotesis menentukan (a) Koefisien Determinasi $\left(\mathrm{R}^{2}\right.$ ), (b) Uji Signifikansi Simultan (Uji Statistik F), (c) Uji Parameter Individual (Uji Statistic t)

\section{Hasil dan Pembahasan Penelitian}

\section{A. Analisis Deskriptif}

Nilai Penilaian Resiko Fraud (Y) rata-rata adalah 4.8107 dengan nilai standar deviasi 0.16912. Tabel 1, menunjukkan bahwa rata-rata nilai Brainstorming (X1) adalah 4.9087 dengan nilai standar deviasi 0.20529. Nilai Keahlian Auditor (X2) rata-rata adalah 4.8826 dengan nilai standar deviasi 0.23693 . 


\begin{tabular}{lll}
\hline \multicolumn{3}{c}{ Tabel 1 Hasil analisa deskriptif } \\
\hline Variabel & Mean & $\begin{array}{l}\text { Std } \\
\text { Deviation }\end{array}$ \\
\hline $\begin{array}{l}\text { Penilaian Resiko Fraud } \\
\text { (Y) }\end{array}$ & 4.8107 & .16912 \\
Brainstorming (X1) & 4.9087 & .20529 \\
Keahlian Auditor (X2) & 4.8826 & .23693 \\
\hline
\end{tabular}

\section{B. Uji Asusmsi Kalsik}

Uji normalitas dilakukan dengan menggunakan analisis statistik non-parametrik Kolmogorov-Smirnov (K-S), Hasil uji K-S, dari tabel 2, dapat dilihat bahwa nilai Signifikan Asimtotik adalah $0,260>0,05$, yang berarti bahwa nilai residu standar dinyatakan terdistribusi normal.

Tabel 2 Hasil uji one-sample kolmogorov-smirnov

\begin{tabular}{ll}
\hline & $\begin{array}{l}\text { Unstandardized } \\
\text { Predicted Value }\end{array}$ \\
\hline $\begin{array}{l}\text { Kolmogorov-Smirnov } \\
\text { Z }\end{array}$ & 1.490 \\
Asymp. Sig. (2-tailed) & .260 \\
\hline
\end{tabular}

Hasil uji multikolinieritas jika nilai hasil VIF kurang dari 10, dari tabel 3, dapat dilihat bahwa semua variabel memiliki nilai VIF lebih kecil dari 10 dan toleransi lebih besar dari 0,1 , data dari penelitian ini dinyatakan bebas dari asumsi multikolinearitas.

Tabel 3 Hasil uji multicollinearity

\begin{tabular}{|c|c|c|}
\hline \multirow[t]{2}{*}{ Variabel } & \multicolumn{2}{|c|}{ Collinearity Statistics } \\
\hline & Tolerance & VIF \\
\hline $\begin{array}{l}\text { Brainstorming } \\
\text { (X1) }\end{array}$ & 1.08 & 9.240 \\
\hline $\begin{array}{l}\text { Keahlian Auditor } \\
\text { (X2) }\end{array}$ & 1.08 & 9.240 \\
\hline
\end{tabular}

Hasil Uji heteroskedastisitas pada tabel 4 menunjukkan bahwa semua variabel tidak memiliki pengaruh signifikan terhadap residu absolut sehingga data dinyatakan bebas dari asumsi heteroskedastisitas.

Tabel 4 Hasil uji glejser method

\begin{tabular}{|c|c|c|}
\hline \multirow[t]{2}{*}{ Variabel } & \multicolumn{2}{|l|}{ Measurement } \\
\hline & $\begin{array}{l}\text { asym. } \\
\text { significance }\end{array}$ & information \\
\hline $\begin{array}{l}\text { Brainstorming } \\
\text { (X1) }\end{array}$ & 0.104 & $\begin{array}{l}>0.05 \text { (a free } \\
\text { form } \\
\text { heteroscedasticity) }\end{array}$ \\
\hline $\begin{array}{l}\text { Keahlian } \\
\text { Auditor (X2) }\end{array}$ & 0.164 & $\begin{array}{l}>0.05 \text { (a free } \\
\text { form } \\
\text { heteroscedasticity) }\end{array}$ \\
\hline
\end{tabular}

\section{Analysis of Multiple Linear Regression}

Berdasarkan data pada tabel 5, beberapa persamaan linear dapat dibuat sebagai berikut:

$\mathrm{Y}=1.987-0,276 \mathrm{X} 1+0,240 \mathrm{X} 2+\varepsilon$

Nilai r-square yang dihasilkan sebesar 0,776 artinya bahwa variasi dalam Penilaian Resiko Fraud dapat dijelaskan oleh variabel Brainstorming dan Keahlian Auditor sebesar $77,60 \%$ sedangkan sisanya $22,40 \%$ dijelaskan oleh variabel lain yang tidak termasuk dalam model. Berdasarkan tes, F Value yang dihitung adalah 19.522 dan $\rho$ value 0.000 pada level 5\%, sedangkan $\mathrm{F}$ tabel pada $\alpha=0,05 \mathrm{df}(\mathrm{k}-1)$ dan (n-k) $=2,790$. Karena F Value $>\mathrm{F}$ table dan Sign $<\alpha=0,05$, dapat disimpulkan bahwa ada efek simultan dari variabel Brainstorming dan Keahlian Auditor pada Penilaian Resiko Fraud dan persamaan regresi dinyatakan baik (goodness of fit). Dasar pengambilan keputusan untuk uji-t parsial dari variabel Brainstorming dan Keahlian Auditor pada Penilaian Resiko Fraud dalam analisis ini, didasarkan pada hasil signifikansi output SPSS, jika sig. $<0,05$, variabel Brainstorming dan Keahlian Auditor berpengaruh signifikan terhadap variabel Penilaian Resiko Fraud.

Tabel 5 Hasil uji regresi linier berganda

\begin{tabular}{lllll}
\hline Variabel & $\begin{array}{l}\text { Unstandar } \\
\text { dized } \\
\text { Coefficient } \\
\text { s } \beta\end{array}$ & $\begin{array}{l}\text { Std } \\
\text { Erro } \\
\mathrm{r}\end{array}$ & value & $\rho$ value \\
\hline $\begin{array}{l}\text { Brainstormi } \\
\text { ng (X1) }\end{array}$ & 1.205 & .276 & 4.357 & $.000^{*}$ \\
$\begin{array}{l}\text { Keahlian } \\
\text { Auditor } \\
(X 2)\end{array}$ & .633 & .240 & 3.642 & $.011^{*}$ \\
\hline
\end{tabular}

* Statistically significant at levelof $\alpha=5 \%$

\section{Hasil Analisa Keseluruhan}

Berdasarkan hasil pengujian diperoleh t hitung 4.357 dengan nilai signifikansi 0,000 , sedangkan koefisien regresi 1.205. Ini menunjukkan bahwa Brainstorming berpengaruh signifikan terhadap Penilaian Resiko Fraud pada level $\alpha=$ $5 \%$, sehingga menolak $\mathrm{H}_{1}=$ Tidak ada pengaruh signifikan Brainstorming terhadap Penilaian Resiko Fraud dan menerima $\mathrm{H}_{0}=$ Terdapat pengaruh yang signifikan Brainstorming terhadap Penilaian Resiko Fraud. Hasil penelitian ini didukung oleh hasil penelitian yang dilakukan oleh Alon dan Dwyer (2010), Carpenter (2007), O'Donnell et al. (2000), Trompeter et al. (2013), Kerr (2013), Kozloski (2011), Hoffman dan Zimbelman (2009), sedangkan hasil ini tidak mendukung hasil penelitian dari Dennis dan Valacich (1993) dan Prasetyo (2018). Hasil penelitian ini, selaras dengan Standar Internasional tentang Audit (ISA International Standart on Auditing) 240 dan Standar Internasional Lembaga-Lembaga Audit Tertinggi (International Standards of Supreme Audit Institutions ISSAI) 1240 yang mendorong auditor untuk mengadakan diskusi dengan anggota tim audit tentang potensi materi salah saji karena fraud. Standar dan panduan juga mendorong penerapan brainstorming selama tugas dalam penilaian resiko fraud.

Berdasarkan hasil pengujian diperoleh t hitung 3.642 dengan nilai signifikansi 0,011, sedangkan koefisien regresi 0.633. Ini menunjukkan bahwa Keahlian Auditor berpengaruh signifikan terhadap Penilaian Resiko Fraud pada level $\alpha=5 \%$, sehingga menolak $\mathrm{H}_{1}=$ Tidak ada pengaruh signifikan Keahlian Auditor terhadap Penilaian Resiko Fraud dan menerima $\mathrm{H}_{0}=$ Terdapat pengaruh yang signifikan Keahlian Auditor terhadap Penilaian Resiko Fraud. Salah satu faktor pendukung utama pengetahuan adalah latar belakang pendidikan seorang auditor, utamanya pendidikan yang terkait ilmu akunatnsi dan audit, dengan 
memhami teori dan konsep dasar audit, seorang auditor akan mampu menganalisis kasus yang ada sesuai dengan prosedur audit sehingga menghasilkan laporan audit yang berkualitas. Seorang auditor dengan latar belakang pendidikan akuntansi dipengaruhi prinsip-prinsip konservatif yang lazim di akuntansi, sehingga skeptisisme profesional jauh lebih baik, sedangkan penempatan auditor tanpa latar belakang pendidikan akuntansi mungkin kurang efektif dalam pemahaman penilaian risiko fraud. Standar Umum tersebut menegaskan bahwa syarat yang harus dipenuhi oleh seorang akuntan untuk melaksanakan audit adalah harus memiliki pendidikan dan pelatihan yang memadai dalam bidang auditing. Kemudian pengalaman seorang auditor juga sangat berperan penting dalam meningkatkan keahlian auditor dalam bidang auditing, berdasarkan paragraf ketiga SA seksi 210 tentang pelatihan dan keahlian independen. Hasil penelitian ini, sesuai dengan penelitian (LaSalle, 2007; Nasir et. All, 2016) serta pendapat Purba (2015:72), dan dalam Mui (2009) serta Bonner \& Lewis (1990) yang menjelaskan bahwa pengetahuan dan kemampuan menyelesaikan masalah merupakan kriteria penting dalam keahlian kinerja auditor. Kedua keahlian ini bisa menjadi kekuatan seorang auditor dalam menyelesaikan masalah kecurangan.

\section{Simpulan Dan Saran}

Tujuan dari penelitian ini, untuk menguji apakah brainstorming dan keahlian auditor berpengaruh terhadap penilaian risiko fraud, berdasarkan hasil uji statistic yang sudah dilakukan bahwa brainstorming dan keahlian auditor berpengaruh terhadap penilaian risiko fraud. Brainstorming berpengaruh terhadap penilaian risiko fraud karena tanpa proses Brainstorming yang tepat, tugas dan kinerja auditor akan terancam, dan auditor mungkin tidak mampu mengidentifikasi risiko fraud selama penilaian risiko fraud serta dengan Brainstorming mendorong auditor untuk mengadakan diskusi dengan anggota tim audit tentang potensi materi salah saji karena fraud. Keahlian auditor berpengaruh terhadap penilaian risiko fraud karena penilaian risiko fraud harus dilakukan oleh Auditor yang memiliki keahlian dan pelatihan yang cukup sebagai Auditor dan bertindak sebagai seorang yang ahli dalam bidang akuntansi dan bidang auditing melalui pendidikan formalnya yang diperluas dengan pengalaman-pengalaman selanjutnya dalam praktik audit. Hasil penelitian bahwa Brainstorming berpengaruh terhadap Penilaian Risiko Fraud didukung oleh hasil penelitian yang telah dilakukan oleh Alon dan Dwyer (2010), Carpenter (2007), O’Donnell et al. (2000), Trompeter et al. (2013), Kerr (2013), Kozloski (2011), Hoffman dan Zimbelman (2009). Hasil penelitian yang menjelaskan Keahlian auditor berpengaruh terhadap penilaian risiko fraud sesuai dengan penelitian LaSalle (2007), Nasir et. All, (2016), Purba (2015:72), dalam Mui (2009) serta Bonner \& Lewis (1990)

Peneliti merekomendasikan untuk penelitian ke depannya, diharapkan untuk menambah referensi factorfaktor lain yang mempengaruhi Penilaian Risiko Fraud serta memperdalam dan mengurai karakteristik Brainstorming dan Keahlian Auditor yang mana yang mempengaruhi Penilaian Risiko Fraud.

\section{REFERENSI}

[1] Alles, M. G., Kogan, A., \& Vasarhelyi, M. A. (2008): Putting Continuous Auditing Theory into Practice: Lessons from Two Pilot Implementations. Journal of Information Systems, 22(2), 195-214. http://doi.org/10.2308/jis.2008.22.2.195

[2] Alon, Anna and Dwyer, Paggy. (2010): The Impact of Groups and Decision Aid Reliance on Fraud Risk Assessment. Management Reserach Review, Vol.33 no.3,pp.240-256

[3] Bastian, I. (2010). Akuntansi Sektor Publik Suatu Pengantar, Jakarata: Erlangga.

[4] Carpenter, T.D. (2007): Audit Team Brainstorming, Fraud Risk Identification, and Fraud Risk Assessment: Implications of SAS No. 99. The Accounting Review, Vol. 82 No. 5, pp. 1119-40.

[5] David Minter dan Michael Reid. (2007). Lightning In A Bottle (Lightning Innovation Strategy), terj. Haris Priyatno, Jakarta: PT. Serambi Ilmu Semesta, hlm. 57.

[6] Dennis, A. R., \& Valacich, J. S. (1993). Computer brainstorms: More heads are better than one. Journal of Applied Psychology. http://doi.org/10.1037/00219010.78.4.531

[7] Dennis, A.R. and Valacich, J.S. (1993): "Computer Brainstorms: More Heads Are Better Than One'. Journal of Applied Psychology, Vol. 78 No. 4, pp. 531-8.

[8] Ghozali, Imam. (2006): Aplikasi Analisis Multivariate dengan Program SPSS. Semarang: Badan Penerbit Universitas Diponegoro.

[9] Karacan, E., \& Yazici, K. (2015): Performance-Based Budget Arrangements, the Implementation Process and Advancements in Turkey. International Journal of Business and Social Science, 62-79, Vol 6, No 4(1)

[10] Kerr, D. (2013): Fraud-risk Factors and Audit Planning: The Effects of Auditor Rank. Journal of Forensic \& Investigative Accounting, 48-76, Vol 5, Issue 2.

[11] Knapp, C. A., \& Knapp, M. C. (2001): The effects of experience and explicit fraud risk assessment in detecting fraud with analytical procedures. Accounting, Organizations and Society, 26, 25-37. http://doi.org/10.1016/S03613682(00)00005-2

[12] Kozloski, T. M. (2011): Knowledge Transfer in the Fraud Risk Assessment Task. Journal of Forensic \& Investigative Accounting, 3(1), 49-85.

[13] LaSalle, R. E. (2007): Effects of the fraud triangle on students' risk assessments. Journal of Accounting Education, 25(1-2), 74-87. http://doi.org/10.1016/j.jaccedu.2007.03.002.

[14] Mohd-Daniel Mohd-Nassir, Zuraidah Mohd-Sanusib, Erlane K. Ghania. (2015): Brainstorming and auditor education background on internal control: Assessing fraud opportunity. International Conference on Accounting Studies (ICAS) 2015 17-20 August 2015, Johor Bahru, Johor, Malaysia

[15] Mohd-Sanusi, Z., Mohamed, N., Omar, N., \& Mohd-Nassir, M.-D. (2015): Effects of Internal Controls, Fraud Motives and Experience in Assessing Likelihood of Fraud Risk. Journal of Economics, Business and Management, 3(2), 194-200. http://doi.org/10.7763/JOEBM.2015.V3.179

[16] Moyes, G. D., \& Hasan, I. (1996): An empirical analysis of fraud detection likelihood. Managerial Auditing Journal, 11(3), 41-46. http://doi.org/10.1108/02686909610115231

[17] Mui, Grace Yanchi. (2009): Factors That Impact On Internal Auditors' Fraud Detection Capabilities - A Report For The Institute of Internal Auditors Australia. Center for Business Forensics HELP University Malaysia.

[18] Nurharyanto. (2009): Dasar-dasar Auditing. Edisi Keenam. Pusat Pendidikan dan Pelatihan Pengawasan Badan Pengawasan Keuangan dan Pembangunan (BPKP). Bogor.

[19] O'Donnell, E., Arnold, V., \& Sutton, S. G. (2000): An Analysis of the Group Dynamics Surrounding Internal Control Assessment in Information Systems Audit and 
Assurance Domains. Journal of Information Systems, 14, 97116. http://doi.org/10.2308/jis.2000.14.s-1.97.

[20] Omar, N., \& Mohamad-Din, H. F. (2010): Fraud Diamond Risk Indicator: An Assessment of Its Importance and Usage. In International Conference on Science and Social Research (pp. 607-612). IEEE. http://doi.org/10.1109/CSSR.2010.5773853

[21] Pincus, K. (1989): The e $\bullet$ cacy of a red 'ags questionnaire for assessing the possibility of fraud. Accounting, Organizations, and Society, 153-163.

[22] Prasetyo, Andrian B. (2017): Dampak Kelompok dan Ketergantungan Bantuan Pengambilan Keputusan pada Penilaian Rresiko Kecurangan. Jurnal Analisa Akuntansi dan Perpajakan, Volome 1, Nomor 1, Maret 2017, Hlm. 1-18

[23] Purba, Bona P. (2015): Fraud dan Korupsi - Pencegahan, Pendeteksian, dan Pemberantasannya. Jakarta:PT Lestari Kiranatama.

[24] Sari, N. N., \& Effendy, H. (2015): Influence Implementation Internal Control To Quality Audit Internal Education Consultant In Indonesian. International Journal of Scientific \& Technology Research, 24-26, Vol 4, Issue 11.

[25] Schuchter, A., \& Levi, M. (2015): Beyond the fraud triangle : Swiss and Austrian elite fraudsters. Accounting Forum, 1-12. http://doi.org/10.1016/j.accfor.2014.12.001.

[26] Smith, M., Omar, N., Sayd Idris, S. I. Z., \& Baharuddin, I. (2005): Auditors' perception of fraud risk indicators: Malaysian evidence. Managerial Auditing Journal, 20(1), 73 85. http://doi.org/10.1108/02686900510570713.

[27] Suryabrata, S. (2000): Metode Penelitian. Jakarta: PT. Raja Grafindo Persada.

[28] Suryani, Eli dan Vanya Ayu H. (2015): Pengaruh Pengalaman, Resiko Audit, dan Keahlian Audit Terhadap Pendeteksian Kecurangan (Fraud) Oleh Audtor (Survey pada KAP Bandung.

[29] Tabak, F., \& Barr, S. H. (1999): Propensity to adopt technological innovations: The impact of personal characteristics and organizational context. Journal of Engineering and Technology Management, 16, 247-270. http://doi.org/10.1016/S0923-4748(99)00011-9 .

[30] Trompeter, G. M., Carpenter, T. D., Desai, N., Jones, K. L., \& Riley Jr., R. A. (2013): A synthesis of Fraud-Related Research. Auditing: A Journal of Practice \& Theory, 32(Supplement 1), 287-321. http://doi.org/10.2308/ajpt50360

[31] Tuanakotta, Theodorus M. (2016): Audit Kontemporer, Jakarta:Salemba Empat.

[32] Yurmaini. (2017): Kecurangan Akuntansi (Fraud Accounting) Dalam Perspektif Islam. Jurnal Akuntansi dan Bisnis , 93-104, Vol 3, No. 1. 